\title{
Infection of the kidney of Acanthopagrus australis (Pisces: Sparidae) with Sphaerospora sp. (Myxosporea), Prosorhynchus sp. (Digenea), and cysts of unknown origin
}

\author{
Frank R. Roubal
}

Department of Parasitology, The University of Queensland, Brisbane, Queensland 4072, Australia

\begin{abstract}
The trunk kidney in $9.7 \%$ of 330 yellowfin bream Acanthopagrus australis from Moreton Bay, SE Queensland, Australia, were infected with Sphaerospora sp. Disporic pseudoplasmodia developed in the glomeruli but chronic infections with mature spores aggregated in the Bowman's capsule were characterised by fibrous encapsulation in thick-walled cysts (IWC), ingress of melanomacrophages and eventual melanisation. There was no qranulomatous response to infection. Spores were rarely found in the head kidney. There was a significant positive association between the occurrence of Sphaerospora sp. and TWCs in the same kidney; TWCs were present in the head kidney as well. TWCs were accumulated in older fish. Metacercariae of Prosorhynchus sp. infected the trunk and head kidney of $9.3 \%$ of $612 \mathrm{~A}$. australis, provoked little tissue response and were progressively melanised. Large cysts (>0.5 mm) of unknown origin were found predominantly in the trunk kidney of $7.8 \%$ of 612 fish. Prevalences of Sphaerospora sp. and thick-walled cysts were not associated with either locality, age or sex of bream in Moreton Bay. Male and female fish at the winter spawning grounds had the highest prevalences of Prosorhynchus sp. and large cysts
\end{abstract}

KEY WORDS: Acanthopagrus - Sphaerospora Kidney Pathology Prosorhynchus CYst

\section{INTRODUCTION}

There have been few studies of the protozoa in Australian marine fish (see review by Lom et al. 1992). Little is known about ecological relationships between myxosporean parasites and their marine fish hosts in Australia. The yellowfin bream Acanthopagrus australis (family Sparidae) is an important commercial and recreational species in Australia with aquaculture potential, but there are few data concerning its protozoan parasites and the ecological factors that affect their prevalence in wild host populations. Certain aspects of the ecology and pathology associated with Henneguya sp. and Myxobolus sp. in A australis were described by Roubal (1994). The present study investigated the ecology and pathology associated with parasite infection and other agents in the kidney of A. australis from Moreton Bay, SE Queensland.
Myxosporean parasites have been described from the kidney of wild and cultured sparids in other parts of the world. Kudoa sp. was found in $85 \%$ of glomeruli in the trunk kidney of $10 \%$ of 1 yr old cultured Sparus aurata L. in France (Paperna 1982). Sphaerospora $5 p$ caused dermal lesions and infected the kidney in $20 \%$ of 18 mo old cultured Sparus aurata in Spain (SitjaBobadilla et al. 1992).

Large cysts ( 2 to $7 \mathrm{~mm}$ ) of unknown origin have been described from all parts of the kidney of wild snapper Pagrus auratus in New Zealand. The cysts occur frequently in large numbers (up to 200, usually 1 to 5) and up to $90 \%$ of the kidney by volume (Hine $\&$ Anderson 1981), but the aetiological agent is unclear (P. M. Hine pers comm.). Systemic granuloma in the kidney of cultured Sparus aurata and Acanthopagrus bifasciatus was associated with accumulated tyrosine (Paperna 1979,1987 ). 
The yellowfin bream has an ovo-testis and undergoes protandrous sex inversion at about 3 yr old (Pollock 1984). Most male and young female bream migrate from the summer grounds in western Moreton Bay to spawn at the surf bars on the eastern side of the bay in winter (Pollock 1982). Juvenile bream remain in the estuaries and shallow inshore mangrove and seagrass areas (Blaber \& Blaber 1980). The influence of locality, host size and sex, and season on the prevalence of kidney infection within the population of yellowfin bream from Moreton Bay is assessed.

\section{MATERIALS AND METHODS}

Individuals of Acanthopagrus australis ( $\mathrm{n}=612$ ) were collected during 1990 and into 1991 by net or handline in 25 samples from different localities within Moreton Bay (Fig. 1) The fish were killed immediately by spinal severance, the body cavity and swim bladder cut open and the fish preserved in $10 \%$ formalin $14 \%$

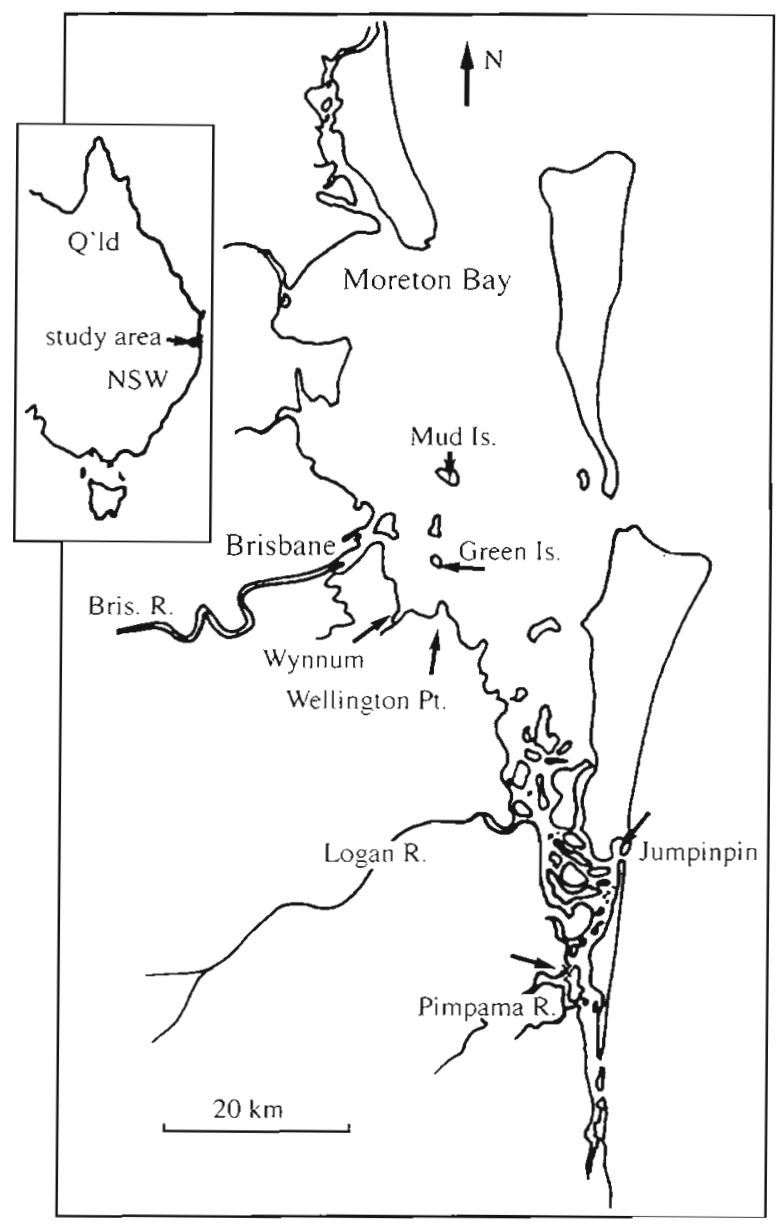

Fig 1. Sample localities in Moreton Bay, SE Queensland, Australia formaldehyde) in sea water. The fish were soaked in several changes of fresh water to remove the formalin and the standard length ( $\mathrm{SL}, \mathrm{cm}$ ) measured.

There was a significant difference $(F=35.8, \mathrm{p}<$ 0.001 ) in the size of fish collected from western Moreton Bay (W.Bay; Green Island, Mud Island, Wynnum, Wellington Point) [average $(X) \mathrm{SL}=16.9$, range $=10.5$ to 23.7 , standard error $(\mathrm{SE})=0.12$, sample size $(\mathrm{n})=$ 396), eastern Moreton Bay (E.Bay; Jumpinpin) ( $X=$ 18.1, range $=12.3$ to $26.4, \mathrm{SE}=0.34, \mathrm{n}=72$ ) and southern Moreton Bay (S.Bay; Pimpama River) $(X=14.7$. range $=5.8$ to $28.5, \mathrm{SE}=0.38, \mathrm{n}=144$ ). There were sig nificant differences in the size of fish among samples from W.Bay $(F=2.75, p=0.003)$, E.Bay $(F=7.9, p<$ $0.001)$ and S.Bay $(F=9.64, \mathrm{p}<0.001)$ (Table 1).

Fish were assigned to age classes based on the studies of age and growth of Acanthopagrus australis in Moreton Bay by Pollock (1984). Age classes (cm) were defined as follows: $0+$, SL $<14.5 ; 1+, 14.5 \leq \mathrm{SL} \leq 18.4$; $2+, 18.5 \leq \mathrm{SL} \leq 21.1 ; 3+$ (and older), $\mathrm{SL}>21.1 \mathrm{~cm}$. The gonads were identified as either male, female, juvenile or intersex (both male and female gametes).

The head and trunk kidney of all fish preserved in formalin were examined for parasites and cysts visible with the dissecting microscope. The head and trunk kidney were removed and stored in $70 \%$ ethanol. Pieces of the head and trunk kidney from a subsample of these fish ( $\mathrm{n}=330$ ), taken from all samples and from all sexes and size classes within these samples, were soaked overnight in concentrated (85\%) lactic acid then squashed on a glass slide beneath a coverslip and examined with a compound microscope. This apparently new technique permitted rapid examination of the kidneys from a large number of preserved fish. All ecological analyses of renal sphaerosporosis are based on presence/absence data for kidneys examined in lactic acid.

Pieces of preserved head and trunk kidney from a few infected fish were dehydrated in alcohol, embedded in wax, serial sections cut at $5 \mu \mathrm{m}$ and stained with haematoxylin and eosin ( $\mathrm{H} \& \mathrm{E}$ ). Pieces of preserved kidney were smeared also in small drops of malten glycerine jelly on glass slides and covered with a coverslip. Measurements of myxosporean spores were made as suggested by Lom \& Arthur (1989). Fresh smears of head and trunk kidney were examined from fish overdosed with benzocaine.

Statistical analyses were done using SAS (SAS Institute Inc., Cary, NC, USA), with a significant probability level of 0.05 . Pearson's chi-squared was used to test for significant differences in prevalence and the association of infection in the head and trunk kidney. Pearson's statistic was also calculated for 2-way contingency tables to test for independence of infection and either locality, sex, age class or season. 
Table 1. Acanthopagrus australis. Prevalence (\%) of Sphaerospora sp. infection and small, thick-walled cysts (TWC) in the trunk kidney, and Prosorhynchus sp. metacercariae and large cysts (LC) (>0.5 mm) in head and trunk kidney. $N_{1}, N_{2}$ : sample sizes; underlined values significantly different by Pearson's $\chi^{2}$ at 0.05 probability level

\begin{tabular}{|c|c|c|c|c|c|c|}
\hline & $N_{1}$ & Sphaerospora & TWC & $N_{2}$ & LC & Prosorhynchus \\
\hline \multicolumn{7}{|l|}{ Locality } \\
\hline Mud Is. & 38 & 10.5 & 23.6 & 58 & 1.7 & 10.3 \\
\hline Wynnum & 25 & 0 & 8.0 & 56 & 1.8 & 3.6 \\
\hline Green Is. & 21 & 9.5 & 23.8 & 88 & 2.3 & 6.8 \\
\hline Wellington Pt. & 97 & 12.4 & 22.7 & 194 & 1.5 & 2.6 \\
\hline W. Bay & 181 & 9.9 & 21.0 & 396 & 1.8 & $\underline{4.8}$ \\
\hline E. Bay & 46 & 6.5 & 28.2 & 72 & 36.1 & $\underline{27.8}$ \\
\hline S.Bay & 103 & 10.7 & 29.1 & 144 & $\underline{10.4}$ & $\underline{12.5}$ \\
\hline \multicolumn{7}{|l|}{ Sex } \\
\hline Juvenile & 41 & 14.6 & 17.1 & 63 & $\underline{1.6}$ & $\underline{1.6}$ \\
\hline Male & 67 & 13.4 & 22.3 & 134 & 15.7 & 13.4 \\
\hline Intersex & 83 & 8.4 & 18.1 & 184 & 1.6 & $\underline{6.0}$ \\
\hline Female & 139 & 7.2 & 31.6 & 231 & $\underline{10.0}$ & 11.7 \\
\hline \multicolumn{7}{|l|}{ Age class } \\
\hline$\tilde{0}+$ & 72 & 11.1 & $\underline{13.9}$ & 115 & 4.3 & $\underline{3.5}$ \\
\hline $1+$ & 153 & 9.8 & $\overline{23.5}$ & 330 & $\underline{7.9}$ & 4.8 \\
\hline $2+$ & 77 & 7.8 & $28 . \overline{5}$ & 130 & $1 \overline{15.4}$ & $\overline{15.4}$ \\
\hline $3++$ & 28 & 10.7 & 46.4 & 37 & 18.9 & 18.9 \\
\hline \multicolumn{7}{|l|}{ Season } \\
\hline Summer & 63 & 9.5 & 20.6 & 164 & $\underline{2.4}$ & $\underline{6.1}$ \\
\hline Autumn & 79 & 8.9 & 20.2 & 134 & 8.2 & $\underline{3.7}$ \\
\hline Winter & 136 & 9.6 & 30.1 & 232 & 14.2 & $\underline{14.7}$ \\
\hline Spring & 52 & 11.5 & 21.1 & 82 & $\overline{\underline{0}}$ & $\underline{9.7}$ \\
\hline
\end{tabular}

\section{RESUITS}

The parasites recovered from the kidney of Acanthopagrus australis include the myxosporean Sphaerospora sp. and metacercariae of the digenean Prosorhynchus sp. A large Philometra-like nematode was found in the trunk kidney of 2 fish. This parasite occurs usually in the nasal sinus, and will not be considered further in this paper. Small $(<200 \mu \mathrm{m})$, frequently melanised, thickwalled cysts (TWC) and large ( $>0.5 \mathrm{~mm}$ ) fibrous cysts of unknown origin were found in the kidney as well.

\section{Occurrence of parasites and cysts}

Spores of Sphaerospora sp. were identified by the slightly apically flattened spherical shape [13.2 (12.0 to $13.9) \times 15.3(13.2$ to 16.4$) \mu \mathrm{m}, \mathrm{n}=15$ ), rounded polar capsules $[4.7$ (4.4 to 5.7$) \times 4.7$ (4.4 to 5.4$) \mu \mathrm{m}$; polar filament with 6 or 7 coils] opposing the level of the suture line (Fig. 2A). In lactic acid preparations, aggregates of spores were found most often within thin-walled cysts [64.6 $\mu \mathrm{m}$ (38.4 to 121.6) $\mu \mathrm{m}$ diameter, $\mathrm{n}=34$; Fig. 2C] and thick-walled, often partly melanised cysts $\{72$ (32 to 102) $\mu \mathrm{m}$ diameter, $\mathrm{n}=30$; Fig. 2D]. Infections in the head kidney were rare and coincided with infection of the trunk kidney. Spores were observed within the renal tubules of one fish only (Fig. 2B).
In histological sections, Bowman's capsules contained aggregations of whole or degenerated spores of Sphaerospora sp. and were encapsulated by a thick layer of proliferated fibrous connective tissue and/or melanised to various degrees in a cyst 62.7 (32 to 128) $\mu \mathrm{m}(\mathrm{n}=28)$ in diameter (Fig. $3 \mathrm{~A}$ to $\mathrm{D}$ ).

Kidney sphaerosporosis was found in $32(9.7 \%)$ of 330 subsampled bream from Moreton Bay [W.Bay: 18 (9.9\%) of 181 bream; E.Bay: $3(6.5 \%)$ of 46 bream; S.Bay: $11(10.7 \%)$ of 103 bream].

Thick-walled cysts [106, (78 to 192) $\mu \mathrm{m}$ in diameter, $\mathrm{n}=61$ ] of uncertain origin had a thick fibrous wall of proliferated connective tissue and were melanised to various degrees (Figs. $2 E$ to $G$ \& 3D). Eighty-one $(24.5 \%)$ of 330 bream from Moreton Bay [W.Bay: 38 $(21.0 \%)$ of 181 bream; E. Bay: 13 (28.3\%) of 46 bream; S.Bay: 30 (29.1\%) of 103 bream) had renal TWC.

There was a significant association $\left(\chi^{2}=15.46, \mathrm{p}<\right.$ $0.001, \mathrm{n}=330$ ) between the occurrence of Sphaerospora sp. and TWCs in the same kidney. Unlike Sphaerospora sp. infection, there was no significant difference in the occurrence of TWC in the head and trunk kidney of the same fish. In some fish there were many melanised TWC and melanomacrophage centres, but the kidneys were not infected with either Sphaerospora sp. or Prosorhynchus sp.

Metacercariae of Prosorhynchus sp. (Fig. 4A to D) were found in the head and trunk kidney and were 

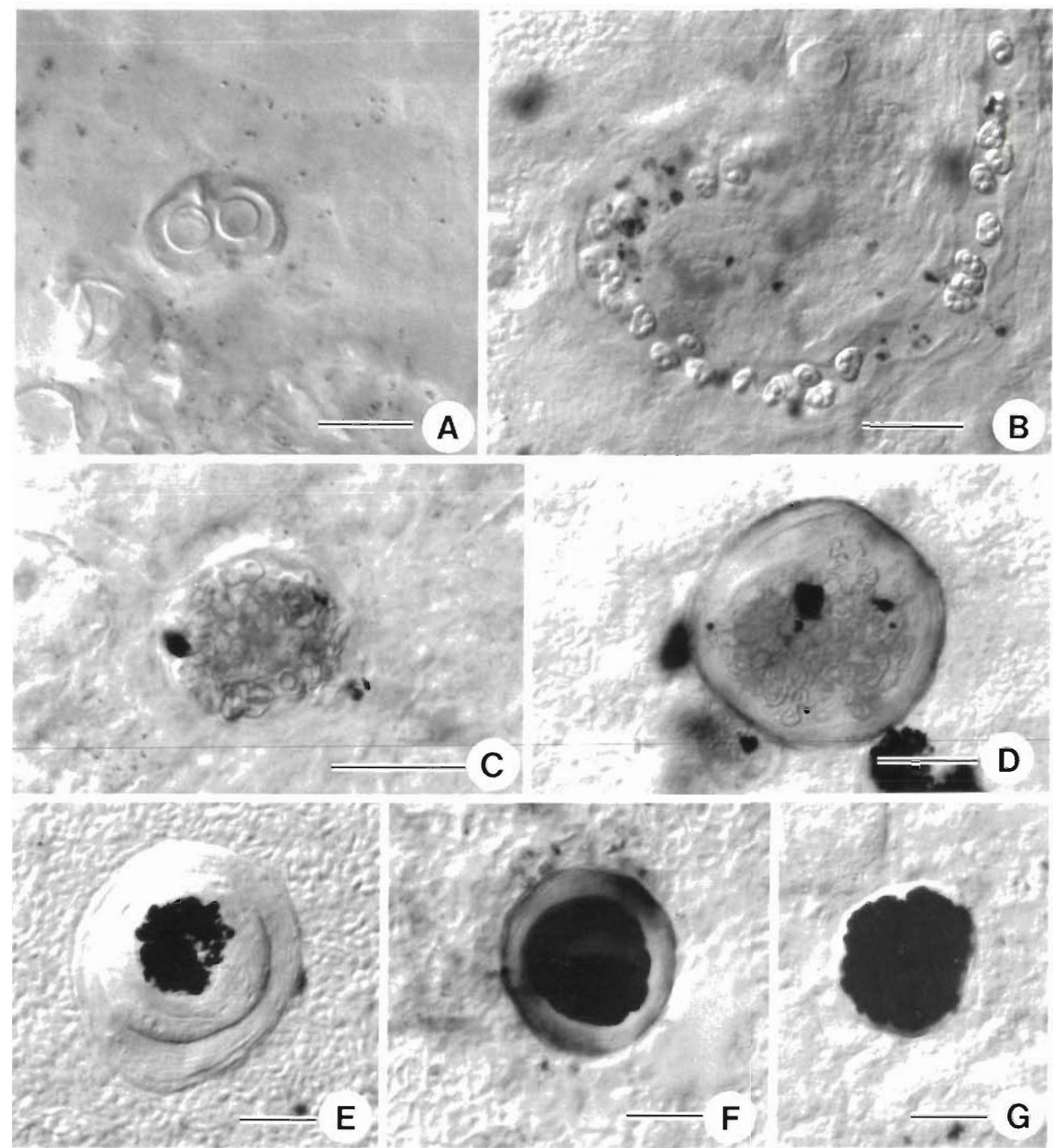

Fig. 2. Renal sphaerosporosis of Acanthopagrus australis: spores and thick-walled cysts in lactic acid preparations. (A) Apically flattened Sphaerospora sp. spore with thick wall and polar capsules opposing suture line. (B) Spores in renal tubule. (C) Aggregate of spores with little tissue response or melanisation. (D) Spores surrounded by thick fibrous cyst and adjacent melanomacrophage centres. Melanin is evident within the encysted plasmodium. ( $E, F, G)$ Possible sequence of progressive melanisation of thick-walled cysts. Scale bar $(\mathrm{A})=10 \mu \mathrm{m}$, others $=50 \mu \mathrm{m}$

much larger than the encysted Sphaerospora aggregates and TWC. Metacercariae were found in 57 $(9.3 \%)$ of the 612 yellowfin bream [W.Bay: $19(4.8 \%)$ of
396 bream; E. Bay: 20 (27.8\%) of 72 bream; S. Bay: 18 $(12.5 \%)$ of 144 bream] that were collected.

Large spherical cysts (>0.5 mm) (Fig. 5A), visible 

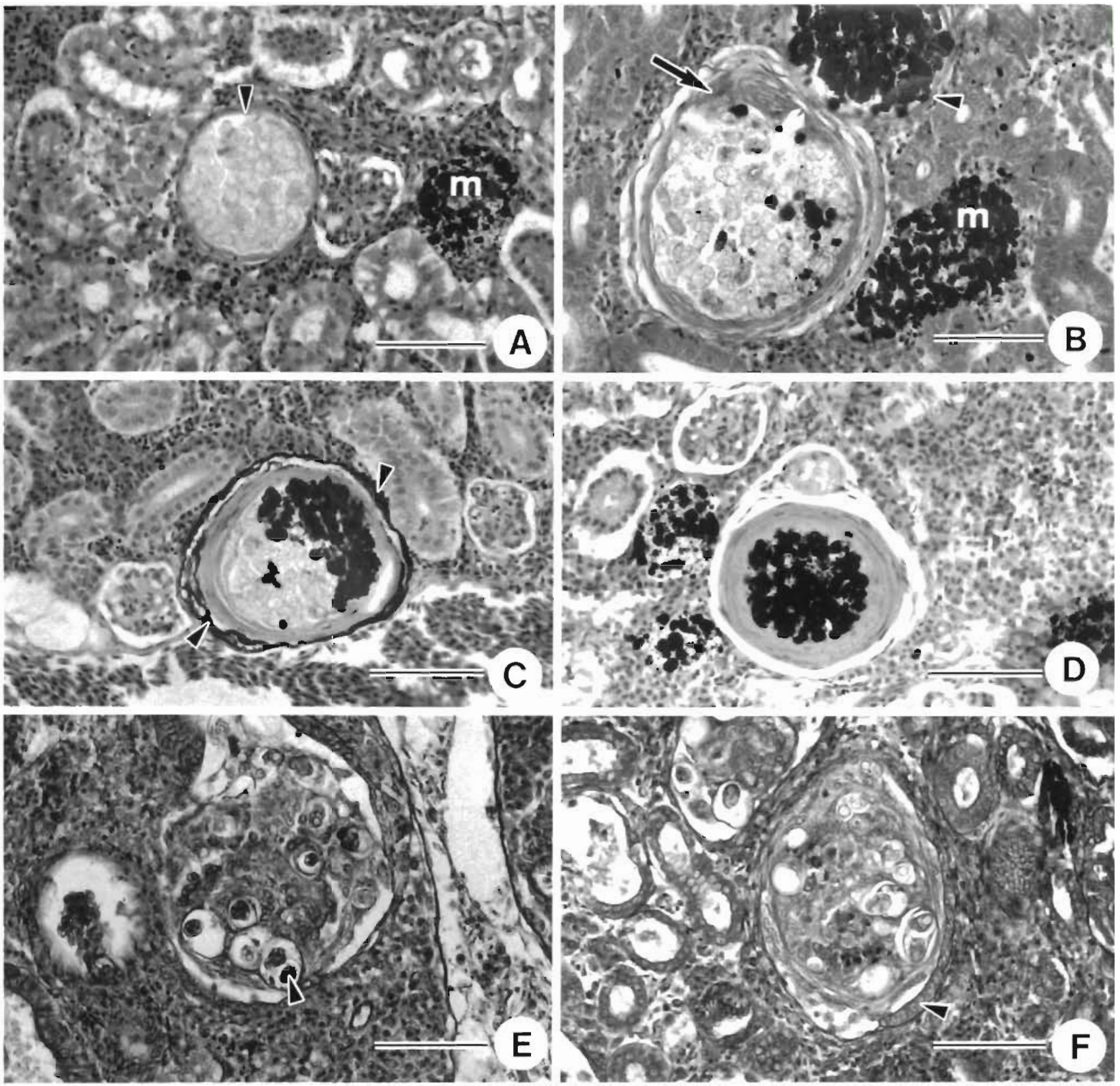

Fig. 3. Histological sections of trunk kidney of Acanthopagrus australis with Sphaerospora sp. (A) Spore aggregate (arrowhead) without any fibrosis, inflammation or encapsulation. Melanomacrophage centre (m) nearby. (B) Thin fibrous capsule (arrow) surrounds spores. Melanomacrophage centres (m) nearby. (C) Thicker fibrous capsule and layer of melanin (arrowheads). Melanin inside cyst. (D) Thick-walled cyst entirely filled with melanin. (E) Spores of Sphaerospora (arrowhead) within hypertrophied glomerulus. (F) Infected renal tubule with flattened epithelium (arrowhead). Scale bars $=50 \mu \mathrm{m}$

with the naked eye and dissecting microscope, were evident in the head and trunk kidney of $48(7.8 \%)$ of 612 bream [W.Bay: $7(1.8 \%)$ of 396 bream; E. Bay: 26 (36.1\%) of 72 bream; S.Bay: $15(10.4 \%)$ of 144 bream] sampled from Moreton Bay. Up to 20 cysts were evident in the kidney of some fish. The cysts were filled with stellar-shaped, fibroblast-like cells (Figs. 5C).

\section{Histopathology}

Infections by Sphaeropsora sp. in the trunk kidney were usually light and caused little pathology without any marked granulomatous response (Figs. $3 \mathrm{~A}$ to $\mathrm{C}$ ). In most cases the mature spores were aggregated in and distended the Bowman's capsule. The squamous, pari- 


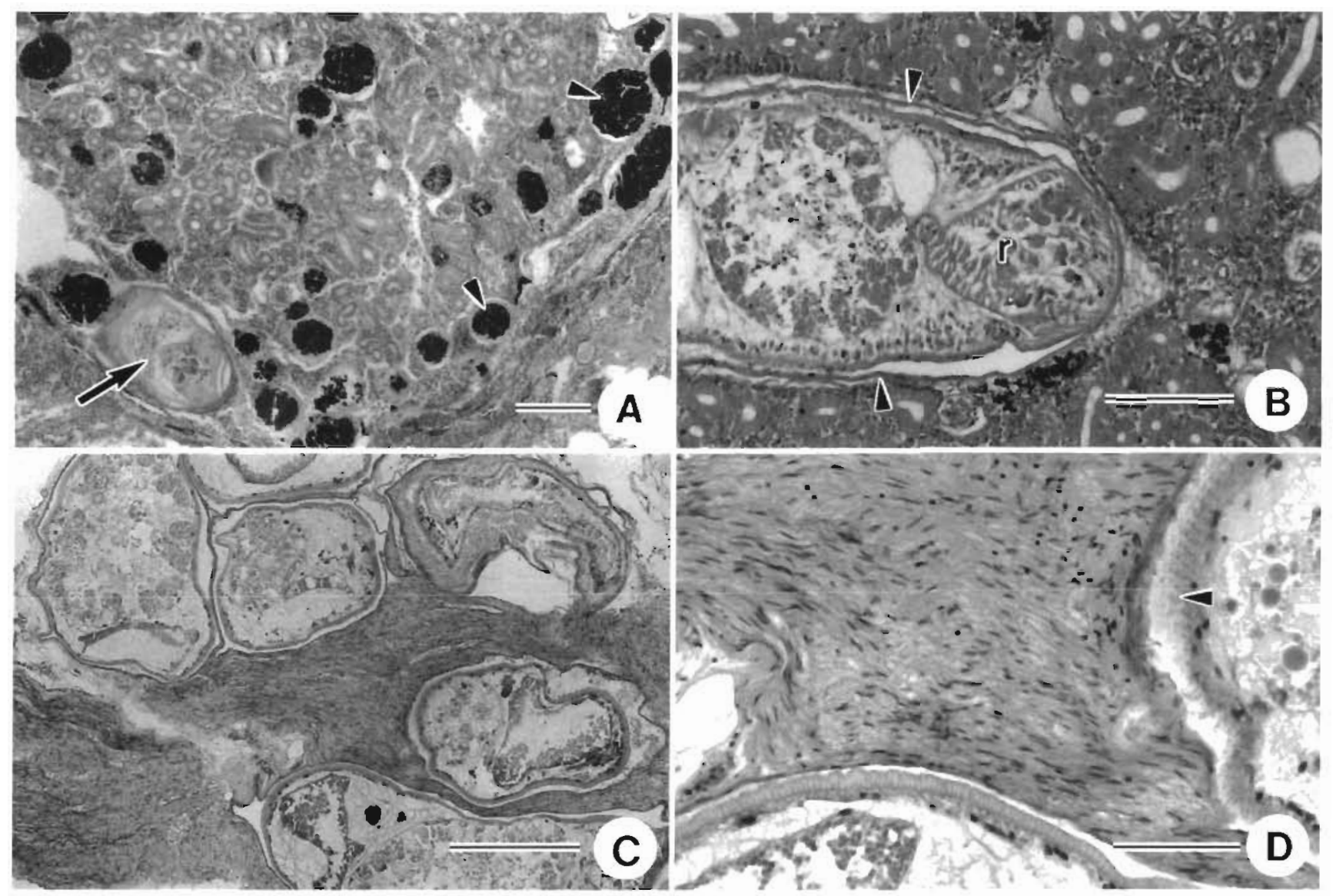

Fig. 4. Metacercariae of Prosorhynchus sp. in kidney of Acanthopagrus australis. (A) Metacercarium (arrow) in trunk kidney. Note the numerous melanised cysts (arrowheads). Scale bar $=100 \mu \mathrm{m}$. (B) Prosorhynchus sp. surrounded by thin capsule (arrowheads). Parasite with characteristic rhynchus (r). Scale bar $=100 \mu \mathrm{m}$. (C) Several metacercariae in connective tissue of head kidney. Scale bar $200=\mu \mathrm{m}$. (D) Enlargement of (C). Note the lack of encapsulation. Surface of parasite covered with spines (arrowhead). Scale bar $=50 \mu \mathrm{m}$

etal epithelium of the capsule was compressed and fibrous connective tissue surrounded the capsule. In some cases the cyst wall was extensively thickened with several layers of connective tissue. Melanomacrophages accumulated on the outside and eventually entered the cyst to engulf mature and dead spores (Fig. 3B, C). Disporous pseudoplasmodia were evident in hypertrophic glomeruli (Fig. 3E) and spores filled and distended some renal tubules (Fig. 3F).

The metacercariae of Prosorhynchus sp. were surrounded by a distinct, thin wall of host origin (Fig. 4A, $B)$ and there was little tissue response associated with the infection (Fig. 4C, D) although a few metacercaria were progressively melanised and destroyed. Melanomacrophage centres adjacent to the parasite capsule were evident in some histological sections.

Melanomacrophage centres (MMC) usually lack a delineating membrane (Fig. 2A), but in some cases a thin layer of connective tissue surrounded the MMC. This fibrous layer increased in thickness and enclosed. the MMC in a thick cyst wall. Thick-walled cysts were not associated with any marked inflammatory response.

The large cysts displaced kidney tissue and reduced the bulk of the kidney (Fig. 5A). There was no inflammation, although mononuclear inflammatory cells could be seen outside the cysts; small numbers infiltrated the outer margin (Fig. 5B). The cysts were pearly white when preserved in formalin and there was no evidence that the large cysts were melanised or resorbed by the fish. Some cysts contained a small central core of unidentified material delineated from the remainder of the cyst contents by a layer of dense connective tissue (Fig. 5D). The identity of this inclusion has yet to be resolved.

\section{Ecological aspects}

There were no significant correlations between either sample size or average fish size per sample and 

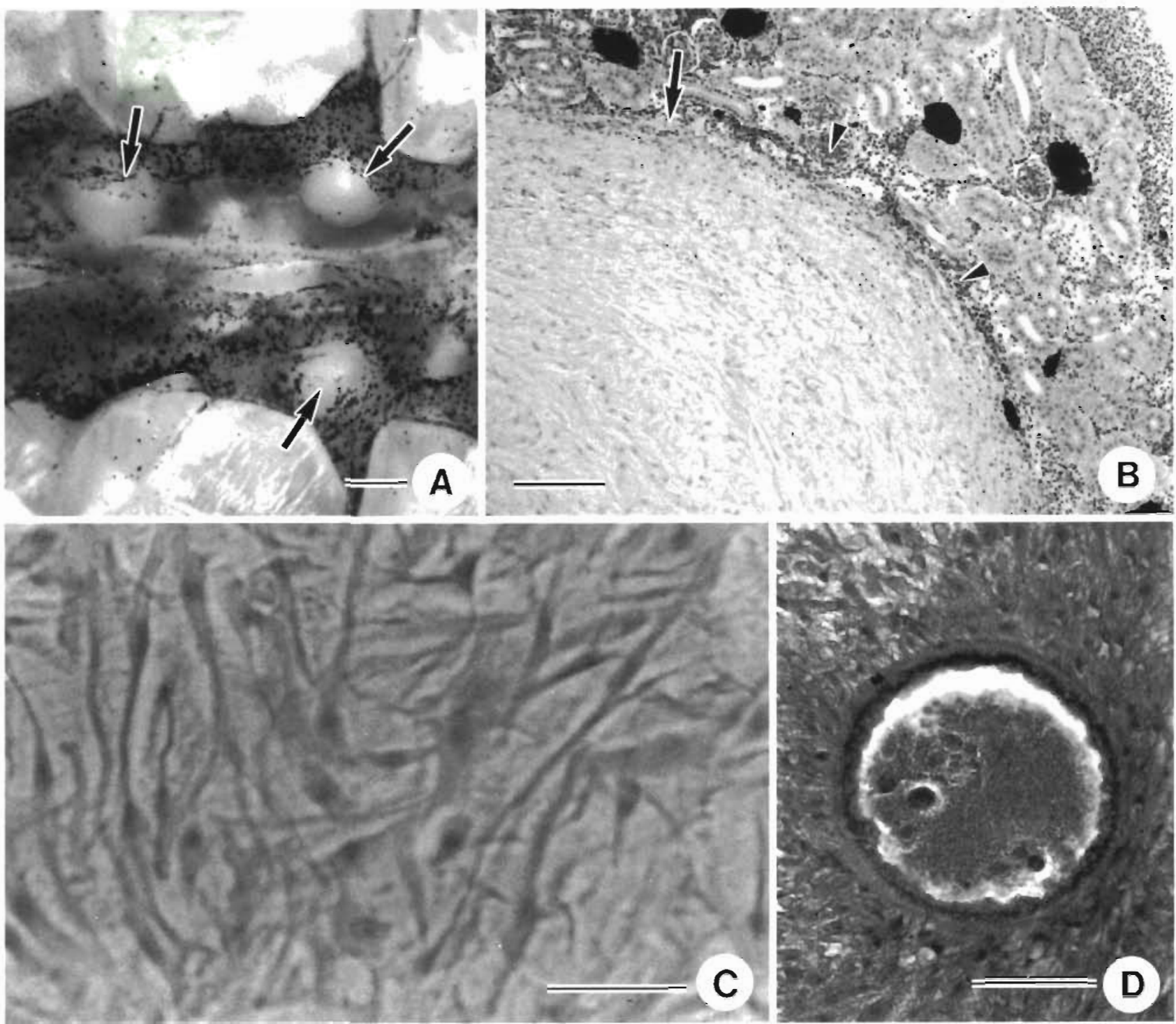

Fig. 5. Large cysts in kidney of Acanthopagrus australis. (A) Large cysts (arrows) in trunk kidney. Scale bar $=1 \mathrm{~mm}$. (B) Histological section of cyst in trunk kidney. Cyst covered with thin capsule (arrow), and inflammatory cells infiltrate outer layer of cyst (arrowheads). Scale bar $=100 \mu \mathrm{m}$. (C) Higher magnification of cyst contents to show stellar, fibroblast-like cells. Scale bar $=20 \mu \mathrm{m}$. (D) Unidentified structure in centre of large cyst separated from cyst contents by layer of eosinophilic material. Scale bar $=50 \mu \mathrm{m}$

the prevalence of either Sphaerospora sp., Prosorhynchus sp., TWC or large cysts. Thick-walled cysts were more prevalent (24.5\%) than either Sphaerospora sp. $(9.7 \%)$, Prosorhynchus sp. $(9.3 \%)$ or large cysts $(7.8 \%)$ over all samples.

The prevalence of both Prosorhynchus sp. and large cysts, but not Sphaerospora sp. and TWC, differed significantly among localities (Table 1). More male and female fish were infected by either Prosorhynchus or large cysts than juvenile and intersex fish, but there was no difference among sexes in the prevalence of either Sphaerospora sp. or TWC (Table 1). There was a significant increase in prevalence with increasing age in Prosorhynchus sp., large cysts and TWC, but age was not associated with prevalence of Sphaerospora sp. over all localities (Table 1). Significant seasonal differences, with highest prevalences in winter, were found for Prosorhynchus sp. and large cysts, but not for Sphaerospora sp. or TWC (Table 1).

There was a significant association between age and prevalence within male fish for Prosorhynchus sp. and large cysts (highest prevalence in $2+$ age class), and between age and prevalence within intersex fish for Prosorhynchus sp. (highest prevalence in 2+ age class) 
Table 2. Acanthopagrus australis. Prevalence (\%) of renal Sphaerospora sp., Prosorhynchus sp., large cysts and thick-walled cysts in of different age within the different sexes. a, b, d, e: prevalence of Sphaerospora sp., thick-walled cysts, Prosorhynchus sp., and large cysts, respectively; $C_{1}$ f: number of fish; there were no significant associations at 0.05 probability level by Pearson's $\chi^{2}$ na: not applicable

\begin{tabular}{|c|c|c|c|c|c|c|c|c|c|c|c|c|}
\hline \multirow[b]{3}{*}{ Juvenile } & \multicolumn{12}{|c|}{ Age $(y r)$} \\
\hline & \multicolumn{3}{|c|}{$0+$} & \multicolumn{3}{|c|}{$1+$} & \multicolumn{3}{|c|}{$2+$} & \multicolumn{3}{|c|}{$3++$} \\
\hline & $\begin{array}{l}{ }^{\mathrm{d}} 16.2 \\
{ }^{\mathrm{d}} 0\end{array}$ & $\begin{array}{l}\mathrm{h} 13.5 \\
\mathrm{e} 1.8\end{array}$ & $\begin{array}{l}(37) \\
\text { ('55) }\end{array}$ & $\begin{array}{c}0 \\
12.5\end{array}$ & $\begin{array}{c}50.0 \\
0\end{array}$ & $\begin{array}{l}(4) \\
(8)\end{array}$ & & $\begin{array}{l}\text { na } \\
\text { na }\end{array}$ & & & $\begin{array}{l}\text { na } \\
\text { na }\end{array}$ & \\
\hline Male & $\begin{array}{r}14.3 \\
6.7\end{array}$ & $\begin{array}{c}0 \\
13.3\end{array}$ & $\begin{array}{r}(7) \\
(15)\end{array}$ & $\begin{array}{l}15.4 \\
10.6\end{array}$ & $\begin{array}{c}20.5 \\
7.1\end{array}$ & $\begin{array}{l}(39) \\
(85)\end{array}$ & $\begin{array}{r}6.2 \\
29.6\end{array}$ & $\begin{array}{l}25.0 \\
40.7\end{array}$ & $\begin{array}{l}(16) \\
(27)\end{array}$ & $\begin{array}{c}20.0 \\
0\end{array}$ & $\begin{array}{l}60.0 \\
28.6\end{array}$ & $\begin{array}{l}(5) \\
(7)\end{array}$ \\
\hline Intersex & $\begin{array}{l}6.7 \\
0\end{array}$ & $\begin{array}{r}20.0 \\
4.0\end{array}$ & $\begin{array}{l}(15) \\
(25)\end{array}$ & $\begin{array}{l}9.4 \\
4.5\end{array}$ & $\begin{array}{c}18.9 \\
0.7\end{array}$ & $\begin{array}{r}(53) \\
(133)\end{array}$ & $\begin{array}{r}7.1 \\
16.7\end{array}$ & $\begin{array}{l}7.1 \\
4.2\end{array}$ & $\begin{array}{l}(14) \\
(24)\end{array}$ & $\begin{array}{c}0 \\
50.0\end{array}$ & $\begin{array}{c}100.0 \\
0\end{array}$ & $\begin{array}{l}(1) \\
(2)\end{array}$ \\
\hline Female & $\begin{array}{c}0 \\
15.0\end{array}$ & $\begin{array}{r}15.4 \\
5.0\end{array}$ & $\begin{array}{l}(13) \\
(20)\end{array}$ & $\begin{array}{l}7.0 \\
9.6\end{array}$ & $\begin{array}{c}28.1 \\
8.6\end{array}$ & $\begin{array}{r}(57) \\
(104)\end{array}$ & $\begin{array}{r}8.5 \\
10.1\end{array}$ & $\begin{array}{l}36.2 \\
10.1\end{array}$ & $\begin{array}{l}(47) \\
(79)\end{array}$ & $\begin{array}{r}9.1 \\
21.4\end{array}$ & $\begin{array}{l}40.9 \\
17.8\end{array}$ & $\begin{array}{l}(22) \\
(28)\end{array}$ \\
\hline
\end{tabular}

(Table 2). No other significant associations were found within the different sexes

There were no significant associations between prevalence and sex of bream within the W.Bay, E.Bay and S.Bay for either Sphaerospora sp., TWC, Prosorhynchus sp. or large cysts (Table 3). There was a significant association between prevalence and age for
TWC, Prosorhynchus sp. and large cysts in the S. Bay, and between prevalence and age for large cysts in the W.Bay. No other significant associations were found between age and prevalence. There was a significant seasonal difference in prevalence only for TWC in the W.Bay, with the greatest prevalence in winter (Table 3).

Table 3. Acanthopagrus australis. Prevalence (\%) of renal Sphaerospora sp., Prosorhynchus sp., large cysts and thick-walled cysts in bream of different sex, age and in different seasons from western (W.Bay), eastern (E.Bay) and southern (S.Bay) Moreton Bay. W. Bay: Mud Island, Wynnum, Green Island, Wellington Point; E. Bay: Jumpinpin; S.Bay: Pimpama River; a, b, d, e: prevalence of Sphaerospora sp., thick-walled cysts, Prosorhynchus sp., large cysts, respectively; c, f: number of fish; underlined values are significantly different by Pearson's $\chi^{2}$ at 0.05 probability level. na: not applicable

\begin{tabular}{|c|c|c|c|c|c|c|c|c|c|c|c|c|}
\hline \multirow{2}{*}{$\begin{array}{l}\text { Sex: } \\
\text { W.Bay }\end{array}$} & \multicolumn{3}{|c|}{ Juvenile } & \multicolumn{3}{|c|}{ Male } & \multicolumn{3}{|c|}{ Intersex } & \multicolumn{3}{|c|}{ Female } \\
\hline & $\begin{array}{l}{ }^{\mathrm{a}} 0 \\
{ }^{\mathrm{d}} 0\end{array}$ & $\begin{array}{l}{ }^{\mathrm{b}} 21.4 \\
\mathrm{e}^{\circ} 0\end{array}$ & $\begin{array}{l}\left({ }^{c} 14\right) \\
(26)\end{array}$ & $\begin{array}{r}18.7 \\
2.7\end{array}$ & $\begin{array}{r}12.5 \\
1.3\end{array}$ & $\begin{array}{l}(32) \\
(74)\end{array}$ & $\begin{array}{l}6.8 \\
5.2\end{array}$ & $\begin{array}{r}16.4 \\
1.2\end{array}$ & $\begin{array}{r}(73) \\
(173)\end{array}$ & $\begin{array}{r}11.3 \\
6.5\end{array}$ & $\begin{array}{r}30.6 \\
3.2\end{array}$ & $\begin{array}{r}(62) \\
(123)\end{array}$ \\
\hline E.Bay & $\begin{array}{c}0 \\
50.0\end{array}$ & $\begin{array}{c}100.0 \\
0\end{array}$ & $\begin{array}{l}(1) \\
(2)\end{array}$ & $\begin{array}{r}9.1 \\
33.3\end{array}$ & $\begin{array}{l}36.4 \\
45.2\end{array}$ & $\begin{array}{l}(22) \\
(42)\end{array}$ & & $\begin{array}{l}\text { na } \\
\text { na }\end{array}$ & & $\begin{array}{r}4.3 \\
17.9\end{array}$ & $\begin{array}{l}17.4 \\
25.0\end{array}$ & $\begin{array}{l}(23) \\
(28)\end{array}$ \\
\hline S.Bay & $\begin{array}{c}37.5 \\
0\end{array}$ & $\begin{array}{r}18.7 \\
2.9\end{array}$ & $\begin{array}{l}(16) \\
(35)\end{array}$ & $\begin{array}{l}33.3 \\
11.1\end{array}$ & $\begin{array}{r}100.0 \\
5.6\end{array}$ & $\begin{array}{l}(3) \\
(18)\end{array}$ & $\begin{array}{l}20.0 \\
18.2\end{array}$ & $\begin{array}{r}30.0 \\
9.1\end{array}$ & $\begin{array}{l}(10) \\
(11)\end{array}$ & $\begin{array}{r}3.7 \\
17.5\end{array}$ & $\begin{array}{l}38.9 \\
15.0\end{array}$ & $\begin{array}{l}(54) \\
(80)\end{array}$ \\
\hline Age class: & \multicolumn{3}{|c|}{$0+$} & \multicolumn{3}{|c|}{$1+$} & \multicolumn{3}{|c|}{$2+$} & \multicolumn{3}{|c|}{$3++$} \\
\hline W. Bay & $\begin{array}{l}4.0 \\
1.9\end{array}$ & $\begin{array}{r}20.0 \\
1.9 \\
\end{array}$ & $\begin{array}{l}(25) \\
(52)\end{array}$ & $\begin{array}{r}11.8 \\
4.6\end{array}$ & $\begin{array}{r}18.3 \\
\underline{0.8} \\
\end{array}$ & $\begin{array}{c}(93) \\
(237)\end{array}$ & $\begin{array}{l}8.3 \\
7.0\end{array}$ & $\begin{array}{r}20.8 \\
1.2 \\
\end{array}$ & $\begin{array}{l}(48) \\
(86)\end{array}$ & $\begin{array}{r}13.3 \\
4.8\end{array}$ & $\begin{array}{l}46.7 \\
14.3 \\
\end{array}$ & $\begin{array}{l}(15) \\
(21)\end{array}$ \\
\hline E.Bay & $\begin{array}{c}0 \\
14.2\end{array}$ & $\begin{array}{c}0 \\
42.8\end{array}$ & $\begin{array}{l}(5) \\
(7)\end{array}$ & $\begin{array}{r}9.1 \\
17.1\end{array}$ & $\begin{array}{l}27.3 \\
22.9\end{array}$ & $\begin{array}{l}(22) \\
(35)\end{array}$ & $\begin{array}{c}0 \\
45.4\end{array}$ & $\begin{array}{l}28.6 \\
54.5\end{array}$ & $\begin{array}{l}(14) \\
(22)\end{array}$ & $\begin{array}{c}0 \\
37.5\end{array}$ & $\begin{array}{l}50.0 \\
37.5\end{array}$ & $\begin{array}{l}(6) \\
(8)\end{array}$ \\
\hline S.Bay & $\begin{array}{r}16.3 \\
3.6 \\
\end{array}$ & $\frac{11.6}{\underline{1.8}}$ & $\begin{array}{l}(43) \\
(56)\end{array}$ & $\begin{array}{r}5.3 \\
15.5 \\
\end{array}$ & $\underline{34.2}$ & $\begin{array}{l}(38) \\
(58)\end{array}$ & $\begin{array}{l}13.3 \\
18.2 \\
\end{array}$ & $\begin{array}{l}53.3 \\
\underline{31.8} \\
\end{array}$ & $\begin{array}{l}(15) \\
(22)\end{array}$ & $\begin{array}{c}0 \\
\underline{37.5} \\
\end{array}$ & $\frac{57.1}{12.5}$ & $\begin{array}{l}\text { (7) } \\
(8)\end{array}$ \\
\hline Season: & \multicolumn{3}{|c|}{$\begin{array}{l}\text { Summer } \\
\text { Dec-Feb }\end{array}$} & \multicolumn{3}{|c|}{$\begin{array}{l}\text { Autumn } \\
\text { Mar-May }\end{array}$} & \multicolumn{3}{|c|}{$\begin{array}{l}\text { Winter } \\
\text { Jun-Aug }\end{array}$} & \multicolumn{3}{|c|}{$\begin{array}{l}\text { Spring } \\
\text { Sep-Nov }\end{array}$} \\
\hline W.Bay & $\begin{array}{l}4.3 \\
5.6\end{array}$ & $\frac{15.2}{2.1}$ & $\begin{array}{r}(46) \\
(144)\end{array}$ & $\begin{array}{l}8.6 \\
2.9\end{array}$ & $\frac{2.2}{3.8}$ & $\begin{array}{l}(58) \\
(105)\end{array}$ & $\begin{array}{r}16.7 \\
3.5\end{array}$ & $\frac{28.6}{0}$ & $\begin{array}{l}(42) \\
(86)\end{array}$ & $\begin{array}{r}11.4 \\
8.2\end{array}$ & $\frac{17.1}{0}$ & $\begin{array}{l}(35) \\
(61)\end{array}$ \\
\hline E.Bay & & $\begin{array}{l}\text { na } \\
\text { na }\end{array}$ & & 0 & $\begin{array}{c}\text { na } \\
100.0\end{array}$ & (3) & $\begin{array}{r}6.5 \\
29.0\end{array}$ & $\begin{array}{l}28.3 \\
33.3\end{array}$ & $\begin{array}{l}(46) \\
(69)\end{array}$ & & $\begin{array}{l}\text { na } \\
\text { na }\end{array}$ & \\
\hline S.Bay & $\begin{array}{l}23.5 \\
10.0\end{array}$ & $\begin{array}{r}35.3 \\
5.0\end{array}$ & $\begin{array}{l}(17) \\
(20)\end{array}$ & $\begin{array}{l}9.5 \\
7.7\end{array}$ & $\begin{array}{l}14.3 \\
15.4\end{array}$ & $\begin{array}{l}(21) \\
(26)\end{array}$ & $\begin{array}{r}6.2 \\
14.3\end{array}$ & $\begin{array}{l}33.3 \\
13.0\end{array}$ & $\begin{array}{l}(48) \\
(77)\end{array}$ & $\begin{array}{l}11.8 \\
14.3\end{array}$ & $\begin{array}{c}29.4 \\
0\end{array}$ & $\begin{array}{l}(17) \\
(21)\end{array}$ \\
\hline
\end{tabular}




\section{Co-occurrence}

Eleven bream (mostly juvenile and female fish from Pimpama River) had branchial Henneguya sp. and renal sphaerosporosis. Only 1 bream $(2+$ age female, Wellington Pt.) had both intestinal Henneguya sp. and renal sphaerosporosis, and 1 bream (1+ age female, Pimpama R.) had both buccal Henneguya sp. and renal sphaerosporosis.

\section{DISCUSSION}

According to Roberts (1989), most Sphaerospora infections in the kidney occur in the glomeruli and renal tubules. Interstitial renal infections with mature spores of Sphaerospora are rare (Lom \& Dyková 1992). Disporic pseudoplasmodia in the renal tubules and Bowman's capsule were rarely seen in Acanthopagrus australis during the present study. This, however, may be attributed to the technique employed. Lactic acid preparations are suitable for determining the presence or absence of mature myxosporean spores, but are less suitable than histological sections to detect the developmental stages.

Developmental stages of Sphaerospora have been observed in the epithelium, glomeruli and lumen of the renal system (e.g. Molnár 1980, El-Matbouli \& Hoffmann 1992, El-Matbouli et al. 1992). Vegetative stages of some Sphaerospora species circulate in the blood to various organs (Csaba 1976, Lom et al. 1983, Baska \& Molnár 1988, Lom \& Dyková 1992) and sporulate in glomeruli and tubules (Molnár \& Kovacs-Gayer 1986, Hedrick et al. 1990, Feist et al. 1991).

The present data indicate that development of Sphaerospora sp. in the kidney of Acanthopagrus australis occurs in the glomeruli and possibly in the renal tubules, but not all spores are shed. Aggregation of mature spores swells the Bowman's capsule in $A$. australis and results in a focal inflammation with fibrous encapsulation, ingress of melanomacrophages that engulf old and dead spores, and eventual melanisation of the cyst. Sitja-Bobadilla et al. (1992) found that light infections by Sphaerospora sp. in the fry of cultured Sparus aurata caused an enlarged Bowman's capsule.

The tissue response in Acanthopagrus australis to Sphaerospora sp. resembles that of the roach Rutilus rutilus to renal infection by Myxidium rhodei (see Dyková et al. 1987). Plasmodia and spores of $M$. rhodei were found in the Bowman's capsule and less frequently in the renal interstitium. Infected glomeruli of $R$. rutilus were compressed and the parietal layer of Bowman's capsule was modified into a thin membrane. Furthermore, in advanced $M$. rhodei infections, the Bowman's capsule was filled with mature spores and was surrounded by a lamellar layer of mature connective tissue with gradual invasion of granulation tissue into the spore mass (Dyková et al. 1987).

Sphaerospora infection in the head kidney of Acanthopagrus australis was rare in the present study, possibly because of the dispersal of pre-sporogenic stages by the blood and uptake in the renal glomeruli of the trunk kidney. Likewise, Hoferellus carasii, agent of kidney enlargement disease in goldfish, affects the trunk kidney but not the head kidney (El-Matbouli et al. 1992).

In the present study, aggregates of Sphaerospora sp. in the head kidney of Acanthopagrus australis were encapsulated in a fibrous cyst and eventually melanised following the ingress of melanomacrophages. Sphaerospora tinca in the head kidney of tench Tinca tinca was also surrounded by a fibrous capsule (Hermanns \& Körting 1985). The spores of Sphaerospora $\mathrm{sp}$. in the head kidney of Sparus aurata were not melanised (Sitja-Bobadilla et al. 1992).

There was a positive association between the occurrence of Sphaerospora and TWC in the same kidney of Acanthopagrus australis, but no difference in the occurrence of TWC in the head and trunk kidney of $A$. australis although Sphaerospora sp. was rare in the head kidney. Although aggregates of Sphaerospora sp. spores in the head and trunk kidney of $A$. australis were encapsulated and melanised, other agents may also cause the formation of TWC. Granulomatous reactions in the kidney of other fish have been attributed to various agents, for example, developmental stages of myxosporean parasites (Dyková et al. 1987. Athanassopoulou \& Sommerville 1993), Mycobacterium, Nocardia, bacterial kidney disease, fungi, deposits of metallic salts and organic compounds (Paperna 1979, 1987, Roberts 1989, Landsberg \& Paperna 1992). There was no marked granulomatous reaction in the kidney of $A$. australis associated with any aetiological agent during the present study. However, most cases of renal sphaerosporosis in A. australis were chronic infections by which time cellular infiltration may have been replaced by fibrosis and melanisation. Dyková (1984) reported that melanomacrophage centres involved in the destruction of trophozoites and mature spores of histozoic myxosporeans in the viscera of some fish were strongly pigmented and often encapsulated in a fibroblastic response.

Ecological data for Sphaerospora sp. in the present study indicate that infection occurs among all age classes and sexes of Acanthopagrus australis. There was no difference in prevalence among localities. There was no seasonal trend in infection, unlike that reported for $S$. dicentrarchi and $S$. testicularis (SitjaBobadilla \& Alvarez-Pellitero 1993), Myxobolus legeri (Molnár 1988) and PKX (Kent \& Hedrick 1985, CliftonHadley et al, 1987) 
The life cycle of marine myxosporeans is unknown, but the involvement of oligochaetes in the life cycle of freshwater myxosporeans is well documented (Markiw \& Wolf 1983, El-Matbouli et al. 1992, Kent et al. 1993). It is not unreasonable to suggest that annelids are involved also in the marine life cycles. The distribution of these putative alternate hosts will influence the distribution of infected fish, especially the juveniles of fish such as Acanthopagrus australis that have limited migrations. Roubal (1994) found that Henneguya sp. infection in $A$. australis was most prevalent in southern Moreton Bay, presumably the result of localised distribution of the alternate host. It would seem that the distribution of the putative alternate host of Sphaerospora $\mathrm{sp}$. is widespread in western and southern Moreton Bay.

There was no accumulation of Sphaerospora sp. infection in Acanthopagrus australis with age, but TWC accumulated in older fish. This suggest a continuous infection with Sphaerospora sp. which become encapsulated and persist in the kidney.

Large cysts in Acanthopagrus australis were found predominantly in the trunk kidney. These cysts resemble those that occur in large numbers in the kidney of snapper Pagrus auratus in New Zealand (Hine \& Anderson 1981). The cause of the cysts is unknown but both Australian and New Zealand material have an unidentified body at the centre of some cysts. The large cysts from A. australis resemble to some extent the cysts of unknown aetiology (CUE) described by MacLean et al. (1987) from the gills of Atlantic mackerel. They differ in size, but both have central inclusions that have yet to be identified.

Like the Prosorhynchus sp. infections in Acanthopagrus australis, the large cysts were most prevalent in adult male and female fish at the winter spawning grounds in eastern Moreton Bay. It would appear that these fish arrive here from areas in Moreton Bay that were not sampled during this study.

The life cycle of Prosorhynchus crucibulum was elucidated by Matthews (1973). The definitive host is Conger conger, the first intermediate host is Mytilus edulis, and 8 fish served as second intermediate hosts. Suttie (unpublished data) found 14 of 14 Acanthopagrus australis in northern Moreton Bay to be infected with metacercariae of Prosorhynchus sp. Adult Prosorhynchus spp. were found in the intestine of flathead fish Suggrundus jugosus and S. harrisii, but these adults did not correspond to Prosorhynchus sp. from $A$. australis. Out of 770 bivalves in 20 species from Moreton Bay, Suttie found only 1 individual of the bivalve Tapes dostaus infected with bucephalid cercariae.

Metacercariae of Prosorhynchus sp. were found in the head and trunk kidney, frequently in the connective tissue, and enclosed in a thin capsule. There was no granulomatous or fibrous reaction. Some metacercariae were melanised, but were much larger than TWC associated with Sphaerospora sp.

None of the aetiological agents found in the kidney of wild Acanthopagrus australis appeared to be significant pathological agents at the observed levels of infection.

Acknowledgements. Mr D. Graham and Ms M. Horton assisted with dissection of fish and Mr W. Clark collected most of the fish from Moreton Bay. This study was supported by the Australian Research Council

\section{LITERATURE CITED}

Athanassopoulou, F., Sommerville, C. (1993). The significance of myxosporean infections in roach, Rutilus rutilus L., in different habitats. J. Fish Dis. 16: 39-51

Baska, F., Molnár, K. (1988). Blood stages of Sphaerospora spp. (Myxosporea) in cyprinid fishes. Dis. aquat. Org. 5: 23-28

Blaber, S. J. M., Blaber, T. G. (1980). Factors affecting the distribution of juvenile estuary and inshore fish. J. Fish Biol. 17: $143-162$

Clifton-Hadley, R. S., Bucke, D., Richards, R. H. (1987). A study of the sequential clinical and pathological changes during profiferative kidney disease in rainbow trout, Salmo gairdneri Richardson. J. Fish Dis. 10: 335-352

Csaba, G. (1976). An unidentified extracellular protozoan parasite from the blood of carp. Parasitol. Hung. 9: 21-24

Dyková, I. (1984). The role of melanomacrophage centres in the tissue reaction to myxosporean infections of fishes. Bull. Eur. Ass. Fish Pathol. 4: 65

Dyková, I., Lom, J., Grupcheva, G. (1987). Pathogenicity and some structural features of Myxidium rhodei (Myxozoa: Myxosporea) from the kidney of the roach Rutilus rutilus. Dis. aquat. Org. 2: 109-115

El-Matbouli, M., Fischer-Scherl, T., Hoffmann, R. W. (1992). Present knowledge on the life cycle, taxonomy, pathology, and therapy of some Myxosporea spp. important for freshwater fish. A. Rev. Fish Dis. 1992: 367-402

El-Matbouli, M., Hoffmann, R. W. (1992). Sphaerospora scardinii n. sp. (Myxosporea: Sphaerosporidae) observed in the kidney of rudd Scardinus erythrophthalmus. Dis. aquat. Org. 14: $23-19$

Feist, S. W., Chilmonczyk, S., Pike, A. W. (1991). Structure and development of Sphaerospora elegans Thélohan 1892 (Myxozoa: Myxosporea) in the sticklebacks Gasterosteus aculeatus L. and Pungitius pungitius L. Eur. J. Protistol. 27: $269-277$

Hedrick, R. P., McDowell, T., Groff, J. M. (1990). Sphaerospora ictaluri n. sp. (Myxosporea: Sphaerosporidae) observed in the kidney of channel catfish, Ictalurus punctatus Rafinesque. J. Protozool. 37: 107-112

Hermanns, W. Körting, W. (1985) Sphaerospora tincae Plehn, 1925 in tench. Tinca tinca L., fry. J. Fish Dis. 8: 281-288

Hine, P. M. Anderson, C. D. (1981). Diseases of the gonads and kidneys of New Zealand snapper, Chrysophrys auratus Forster (f. Sparidae). In: Fowler, M. E. (ed.) Wildlife diseases of the Pacific basin and other countries. Proc. 4 th Int. Conf. Wildlife Dis. Ass., Sydney 25-28 Aug, 1981, p. $166-170$

Kent, M. L.. Hedrick, R. P. (1985). PKX, the causative agent of proliferative kidney disease (PKD) in Pacific salmonid 
fishes and its affinities with the Myxozoa. J. Protozool. 32: $254-260$

Kent, M. L., Whitaker, D. J., Margolis, L. (1993). Transmission of Myxobolus arcticus Pugachev and Khokhlov, 1979, a myxosporean parasite of Pacific salmon, via a triactinomyxon from the aquatic oligochaete Stylodrilus heringianus (Lumbriculidae). Can. J. Zool. 71. 1207-1211

Landsberg, J. H., Paperna, I. (1992). Systemic granuloma in goldfish caused by a Dermocystidium-like aetiological agent. Dis. aquat. Org. 13:75-78

Lom, J., Arthur, J. R. (1989). A guideline for the preparation of species descriptions in Myxosporea. J. Fish Dis. 12: $151-156$

Lom, J., Dyková, I. (1992). Protozoan parasites of fishes. Elsevier Science Publishers, Amsterdam

Lom, J., Dyková, I., Pavlaskova, M., Grupcheva, G. (1983). Sphaerospora molnari sp. nov. (Myxozoa: Myxosporea), an agent of gill, skin and blood sphaerosporosis of common carp in Europe. Parasitology 86: 529-535

Lom, J., Rohde, K., Dyková, I. (1992). Studies on protozoan parasites of Australian fishes I. New species of the genera Coccomyxa Leger et Hesse, 1907, Ortholinea Shulman, 1962 and Kudoa Meglitsch, 1947 (Myxozoa, Myxosporea). Folia Parasit. 39: 289-306

MacLean, S. A., Morrison, C. M., Murchelano, R. A., Everline, S., Evans, J. J. (1987). Cysts of unknown etiology in marine fishes of the Northwest Atlantic and Gulf of Mexico. Can. J. Zool. 65: 296-303

Markiw, M. E., Wolf, K. (1983). Myxosoma cerebralis (Myxozoa: Myxosporea) etiological agent of salmonid whirling disease requires tubificid worm (Annelida: Oligochaeta) in its life cycle. J. Protozool. 30: 561-564

Matthews, R. A. (1973). The life-cycle of Prosorhynchus crucibulum (Rudolphi, 1819) Odhner, 1905, and a comparison of its cercaria with that of Prosorhynchus squamatus Odhner, 1905. Parasitology 66: 133-164

Molnár, K. (1980). Renal sphaerosporosis in the common carp Cyprinus carpio L. J. Fish Dis. 3: 11-19

Responsible Subject Editor: W. Körting, Hannover, Germany
Molnár, K. (1988). Development of Myxobilatus legeri in cyprinid fishes. Dis. aquat. Org. 4: 181-187

Molnár, K., Kovacs-Gayer, E. (1986). Observations on the intracellular and coelozoic developmental stages of Hofferellus cyprini (Doflein, 1898) (Myxosporea, Myxozoa). Parasit. Hung. 19: 27-30

Paperna, I. (1979). Systematic granulomatosis, a diet-related disease in gilt-head bream, Sparus aurata L., in marine culture. Proc. World Symp. Finfish Nutrition Fishfeed Tech. 2: 369-376

Paperna, I. (1982). Kudoa infection in the glomeruli, mesentery and peritoneum of cultured Sparus aurata L. J. Fish Dis. 5: $539-543$

Paperna, I. (1987). Systemic granuloma of spariid fish in culture. Aquacuiture 67: 53-58

Pollock, B. R. (1982). Movements and migrations of yellowfin bream, Acanthopagrus australis (Günther), in Moreton Bay, Queensland as determined from tag recoveries. J. Fish Biol. 20: 245-252

Pollock, B. R. (1984). Relations between migration, reproduction and nutrition in yellowfin bream Acanthopagrus australis. Mar. Ecol. Prog. Ser. 19: 17-23

Roberts, R. J. (1989). Fish pathology, 2nd edn. Bailliere Tindall, London

Roubal, F. R. (1994). Histopathological and ecological aspects of Henneguya and Myxobolus (Myxosporea) infection in Acanthopagrus australis (Günther) (Pisces: Sparidae) from Moreton Bay, Australia. J. Fish Dis. 17: in press

Sitja-Bobadilla, A., Alvarez-Pellitero, P. (1993). Population dynamics of Sphaerospora dicentrarchi Sitja-Bobadilla et Alvarez-Pellitero, 1992 and S. testicularis Sitja-Bobadilla et Alvarez-Pellitero, 1990 (Myxosporea: Bivalvulida) infections in wild and cultured Mediterranean sea bass (Dicentrarchus labrax L.). Parasitology 106: 39-45

Sitja-Bobadilla, A., Franco-Sierra, A., Alvarez-Pellitero, P. (1992). Sphaerospora (Myxosporea: Bivalvulida) infection in cultured gilt head sea bream, Sparus aurata L.: a preliminary report. J. Fish Dis. 15: 339-343

Manuscript first received: March 22, 1994

Revised version accepted: July 17, 1994 